\title{
Socially Critical Humor: Discussing Humor with Erich Fromm and Theodor W. Adorno ${ }^{1}$
}

\author{
Jarno Hietalahti ${ }^{2}$
}

\begin{abstract}
This article brings Erich Fromm and Theodor W. Adorno back into dialogue by discussing the cultural phenomena of humor and laughter based on their theoretical writings. I argue that what is typically considered socially critical humor, like offensive jokes or harsh satire, often fails to meet the preconditions of criticism in the light of Adorno's and Fromm's thinking. Humor, to be socially critical, has to be life-affirmative and non-positional, and it has to challenge the limits of humor. It is also claimed that in this scope, humor cannot be instrumental.
\end{abstract}

Keywords: E. Fromm; T. W. Adorno; Social criticism; Humor; Laughter.

Humor socialmente crítico: discutindo humor com Erich Fromm e Theodor W. Adorno

Resumo: O artigo recoloca Erich Fromm e Theodor W. Adorno em diálogo ao analisar os fenômenos culturais do humor e do riso com base em seus escritos teóricos. Argumento que o que é tipicamente considerado humor socialmente crítico, como piadas ofensivas ou sátiras ríspidas, frequentemente falha em alcançar as précondições da crítica à luz do pensamento de Adorno e Fromm. O humor, para ser socialmente crítico, deve ser afirmativo da vida e não posicional, e deve desafiar os limites do humor. Afirma-se também que, neste contexto, o humor não pode ser instrumental.

Palavras-chave: E. Fromm; T. W. Adorno; Crítica social; Humor; Riso.

Humor socialmente crítico: discusión sobre el humor con Erich Fromm y Theodor W. Adorno

Resumen: Este artículo vuelve a poner a Erich Fromm y a Theodor W. Adorno en diálogo al analizar los fenómenos culturales del humor y la risa con base en sus escritos

\footnotetext{
${ }^{1}$ Received on 29/08/2016 and accepted for publication on 14/12/2016.

2 Post-doctoral researcher in Philosophy at the University of Jyväskylä (Finland). This paper was written during a research period at the Erich Fromm Institute (Tübingen, Germany). E-mail: jarno.hietalahti@jyu.fi.
} 
$|88|$

Socially Critical Humor: Discussing Humor...

teóricos. Argumento que lo que normalmente se considera humor socialmente crítico, como las bromas ofensivas o las sátiras ácidas, suele no satisfacer los requisitos de la crítica, a la luz del pensamiento de Adorno y Fromm. Para ser socialmente crítico, el humor debe ser afirmativo de la vida y no posicional, y debe desafiar los límites del humor. Además, en este contexto, el humor no puede ser instrumental.

Palabras clave: E. Fromm; T. W. Adorno; Crítica social; Humor. Risa.

\section{Introduction}

The goal of this article is to analyze the concept of socially critical humor based on the theoretical discussions by Erich Fromm and Theodor Wiesengrund Adorno, both of whom were central figures of the Frankfurt School's Critical Theory. There have been some attempts to formulate socially critical perspectives on humor, like those of Michael Billig (2005), and plenty of discussion about whether humor is a critical or a conservative power (see KUIPERS, 2008). The position offered here is different from previous research: it challenges the very foundations of humor, and it is argued that to be socially critical, it is not sufficient to, say, merely joke about political topics. This text is motivated by the question: why does our (at least seemingly) most innocent attribute, humor, descend into cruelty? To answer this question, Fromm's and Adorno's social theories will be brought together, and in this sense, the hope is to bring these two social critics back to a reciprocal discussion which may give birth to something new and fruitful. This task is based on the idea that deep questions about humanity and society presented by Fromm and Adorno are central also in humor research. It will be shown that humor is not an entity which is separated from other human features, but instead our fun and mirth intertwine with other human attributes and worldviews.

The personal conflicts between Fromm and Adorno (see MCLAUGHLIN, 1999; MÜLLER-DOOHM，2005; FRIEDMAN, 2013) will not be discussed here. Instead, the task in this article is to compare their independent thoughts on humor and laughter, 
and to draw a unified picture of their criticism on the subject matter; thus, I reconstruct a theoretical position on humor from their intellectual fragments. By discussing the shared critical point and analyzing how their critical thought complement each other, this article offers an analysis of how humor can be socially critical, and questions certain contemporary traits of humor.

Despite the personal and intellectual disagreements between Fromm and Adorno, the similarities between these two theorists are striking. They both experienced the diversity of cultural forms of life, and tensions between tradition and modernity. As will be shown, they both criticized the prevailing social-economic-cultural setting, and humor as a part of it. They both accepted the idea that cultural criticism is a way to break shared illusions which strengthen the prevailing societal insanity. Since his childhood, Fromm was puzzled by the question "How is it possible?" (FROMM, 1962), as he tried to understand the destructive tendencies of the overarching culture despite the fact that life is full of positive creative possibilities. Adorno, together with Max Horkheimer, focused on the same problem, and asked: why does the world fall over and over again into barbarism even though we are more intelligent and knowledgeable than ever? The analysis focused on the Enlightenment which had been twisted to a form of caricature of itself (HORKHEIMER \& ADORNO, 1947).

For conceptual clarity, humor is understood as an umbrella concept which covers different genres of humor from farce to slapstick and from irony to parody. The concept of humor is understood along the lines of incongruity theory which essentially claims that humor is based on a contradiction of cultural categorizations; to put it another way, humor stems from a conflict between an expectation about an incident, and an actual incident (for a detailed take on incongruity theory, see ORING, 2003). In addition, laughter refers to laughter triggered by humor. ${ }^{3}$

\footnotetext{
${ }^{3}$ As the discussion is on the general level of humor as a cultural phenomenon, minute differences between, for instance, amusement and mirth, are not taken into focus. Also, concrete humorous examples will be relatively few.
} 
|90|

Socially Critical Humor: Discussing Humor...

The article is structured as follows: First, the critique of humor and laughter by Adorno and Fromm will be discussed, and secondly, the life-affirmative possibilities of humor will be analyzed. Thirdly, the preconditions of socially critical humor will be offered, and lastly, the article ends with conclusions and future prospects for a critical theory of humor.

\section{Critique of Humor and Laughter}

With their theoretical writings, Fromm and Adorno offer caveats against overtly positive attitudes towards humor. They challenge widely shared beliefs that humor is mostly innocent (see BILLIG, 2005) and greatly beneficial for, say, forming romantic relationships (see GRAY et al., 2015) and for one's health (see LEWIS, 2006). When researchers encourage people to laugh every chance they get (SEPPÄL ̈̈, 2015), Fromm and Adorno lift the veil of positivity and formulate critical perspectives on humor and laughter. Instead of embracing the positive hype about humor, Adorno offers an anti-thesis: "The collective of those who laugh parodies humanity" (HORKHEIMER \& ADORNO, 1947, p. 112). When headlines shout that smiling is the key to success and to changing one's life (BAKER, 2012), this suggestion is hard to accept, as even smiles have become merely automatic responses which are detached from what they are supposed to express, like cheerfulness and friendliness (FROMM, 1941, p. 251). Our laughter and smiles appear to be false.

Fromm and Adorno challenge the naïve assumptions about humor, and it becomes clear that humor is a cultural product. Adorno is concerned with how the culture industry - and humor as a part of it - has a dulling and draining influence on individuals and societies (HORKHEIMER \& ADORNO, 1947), and similarly, Fromm criticizes the fact that the logic of capitalism has become the leading principle of human life (FROMM, 1947). If the sense of humor is supposed to be a unique human feature and a manifestation of individuality (see RUCH, 1998), it is concerning if the social-economic-cultural setting twists this unique feature, 
making us homogenous with everyone else: "Culture today is infecting everything with sameness" (HORKHEIMER \& ADORNO, 1947, p. 94).

Even though, say, Walt Disney movies are seemingly innocent, Fromm criticizes Mickey Mouse pictures (FROMM, 1941, p. 140), and Adorno scorns Donald Duck cartoons (HORKHEIMER \& ADORNO, 1947, p. 110). Adorno is certain that every time he went to movies, he came out stupider and worse (ADORNO, 1951). Fromm, in a similar manner, writes that television is such a hypnotic device that the viewer actually loses a bit of his freedom as there is no room for any kind of genuine experience (FROMM, 1983, p. 93). They both move beyond the superficial innocence of various cultural products, and offer an argument on how the logic of entertainment business grasps also the everyday life. The freedom promised by entertainment is actually a continuation of work - it is not freedom to but instead freedom from (see FROMM, 1941); in the sphere of amusement this means freedom from independent thought, as the very root of our fun is in powerlessness (HORKHEIMER \& ADORNO, 1947, p. 116). When watching comedies, we run away from ourselves and our possibilities to flourish as human beings - cheap fun offers a route to escape from the problems which we are not willing to face (see FROMM, 1941). The tragic problem of humor is that fun does not cure the underlying problem, the aching boredom or ennui which threatens the very sanity of our lives (see FROMM, 1983). The culture industry does not aim to cure people but instead offers easy medicine so that the never-ending cycle is not threatened: "Fun is a medicinal bath which the entertainment industry never ceases to prescribe. It makes laughter the instrument for cheating happiness. [...] It is not the bells on the fool's cap that jingle but the bunch of keys of capitalist reason" (HORKHEIMER \& ADORNO, 1947, p. 112, 114).

A liberalist might argue that we are free to choose from a wide scope of possibilities. However, Adorno points out that this is precisely the problem: "Something is provided for everyone 
so that no one may escape" (HORKHEIMER \& ADORNO, 1947, p. 97). Nothing outside of the menu, so to speak, is ever offered. As long as the logic of capitalism rules over amusement, the comedies and sketch shows filling television networks and Internet channels are competing mainly for popularity, and to become popular, they cannot be too divergent from consumers' pre-existing tastes. The freedom offered by humor, despite its superficial diversity, is eventually the freedom to be the same. Following Fromm and Adorno, this overarching sameness and never-ending repetition are the central problems of contemporary humor.

In addition, Fromm and Adorno are concerned about the influence of the shared humor on the way of being. The logic of the culture industry does not only permeate produced TV and Internet comedies, but also the ways in which we understand humor in our everyday lives. If humor is considered as a tool for forming relationships, or to become more charming in the eyes of a prospective partner, or if it is a means for making life easier, then there is already an instrumental reason operating behind our relation to humor. In this regard, it is crucial to analyze how, with humor and laughter, we can betray ourselves as human beings.

There is, of course, a long history of arguments on how humor brings people together and laughter reinforces the group: humor is social, laughter is always shared, and as this mirthful way of socializing is essential in human life, therefore humor is good (e.g. BERGSON, 1913; PROVINE, 2000). If a study focuses solely on humor, these aspects of humor are hard to deny. However, Fromm and Adorno question the foundation of the prevailing social way of living. Fromm argues that a whole society can be sick without even noticing it (FROMM, 1955), and this notion is elemental for a critical theory of humor: our founding premises about humor can be wrong, too. Whereas disparagement theories (see FERGUSON \& FORD, 2008) point out that humor can have harmful consequences (a cruel joke may be offensive and hurtful), Fromm and Adorno take a step forward: the instant consequences of humor are not enough when evaluating humor. The whole scope of being has to 
be taken under critical scrutiny; only in relation to the question of what it means to be a human being can the significance of humor be understood.

The central idea here is that the evaluation of humor has to be based on the evaluation of the current social system and humor within it. True, in many recent humor studies (e.g. ORING, 2003; DAVIES, 2011) it is emphasized that humor always happens within a certain context and that we have to be aware of these contexts to grasp the effects of humor; however, critical theorists, as it has been noted, go beyond these spheres. This type of theory is not satisfied with the context-sensitive approaches but questions the whole context itself; a critical theory of humor goes to the roots of humor and humanity.

As humor is generally considered to be innocent, and because mirth feels so good, it is hard to question one's own sense of humor. In addition, if we are not in control of our own feelings of amusement, then our sense of humor cannot be wrong (SMUTS, 2010). Unfortunately, this simplistic claim is untenable. Undoubtedly, it would be most liberating to remove the responsibility of a laughing agent and state that we cannot be blamed if we happen to laugh at something. Fromm and Adorno challenge this position, and it is possible to claim that our shared sense of humor can be wrong. For Bergson (1913) and Provine (2000), the shared moment of humor and laughter is generally a positive force as it brings people together. However, Frankfurt School's critical theorists question this assumption.

Adorno describes how "In wrong society laughter is a sickness infecting happiness and drawing it into society's worthless totality" (HORKHEIMER \& ADORNO, 1947, p. 112). This notion is closely linked to the central problem presented in this article: the sense of humor is thought to be a unique personal feature, as everyone has his or her own individual way of understanding and experiencing humorous events and things in the world. Fromm and Adorno point out how the culture industry distorts this unique and private attribute of life, and how humor becomes 
|94|

Socially Critical Humor: Discussing Humor...

a product of industry which is offered to masses. In this process the most individual expression of personality and individual freedom appears to be merely a mass product, something which is - despite the minute differences between people - the same for all. In this process, both an individual and the totality around him or her are false.

The central piece of both of these thinkers' criticism is that to succeed in self-preservation in a sick society, one has to give up himor herself. Even if the society superficially promotes individuality, it is actually demolishing a genuine human uniqueness. Their shared concern is that basically all humor in the prevailing society is penetrated by capitalistic logic, and for this reason humor is alienated; it is merely a commodity whose value is its exchange value. This concern also applies to everyday human relationships. This socially necessary illusion is accepted by most: we tend to act - even when having fun - as we are needed to act, and the tragedy is that we want to act in this manner even if in doing so we trample on humanity (see FROMM, 1941). The grasp of humor is so dominant that it is hard to resist. The never-ending race to be as funny as possible - among both the culture industry and everyday encounters - appears to be, in this respect, problematic. Humor becomes empty and laughter is merely a peak experience which empties itself as suddenly as it is experienced. This kind of humor is not the spontaneous manifestation of autonomy, but organized fun which is manufactured from above.

\section{Possibilities of Humor}

Despite the deeply pessimistic stance on humor offered by Fromm and Adorno, they are not entirely hopeless. Adorno claims that whoever is to "experience the truth of immediate life, must investigate its alienated form" (ADORNO, 1951, §1). Both Adorno and Fromm hint that there can be an authentic position on humor, and the prevailing societal absurdity is to be analyzed to open this position; Adorno notes that the life does not live in the current social system, and how consumption-filled life is merely a 
caricature of true life (ADORNO, 1951). If the whole of life appears to be just a mismatch, then we are in the middle of a deep crisis. The implication is that this crisis is also present in the modern catalogues of humor.

Even though it is easy to pick clearly negative slogans about laughter by both Adorno and Fromm, they leave room for optimism in relation to humor. There have been claims that Adorno would promote maxims like "Stop laughing!" (FEUER, 2015), but these kinds of simple suggestions do not reach his dialectic position on humor. Humor has to be interpreted in relation to the prevailing essentials of humanity itself. Even if laughter in the sphere of the culture industry is a sign of ennui (see FROMM, 1983), or to put it more dramatically, a sign of violence, "it nevertheless contains the opposite element, in that through laughter blind nature becomes aware of itself as such and thus abjures its destructive violence" (HORKHEIMER \& ADORNO, 1947, p. 60). Adorno does not give clear instructions as to how this kind of laughter actually works, but in this short quotation he affirms the positive possibilities of humor and laughter - we can become aware of the destructive tendencies of our amusement. Fromm strongly objects to learned patterns of laughter and fun because they are hollow (see FROMM, 1976). According to Adorno, this "is the secret of the 'keep smiling' attitude. The face becomes a dead letter by freezing the most living thing about it, namely its laughter" (ADORNO, 1991, p. 95). In a life-affirmative interpretation, humor should be something alive, and laughter a genuinely spontaneous expression of joy (see FROMM, 1976). This moment of humorous realization has a critical potential which can reveal the insanity of a sick society. Thus, laughter can be a form of resistance when there are forces which threaten humanity. Because of this, even philosophy should not forget its clownish traits: "Philosophy is the most serious thing, but then again it is not all that serious" (ADORNO, 1966, p. 14).

When rigid reason strangles human life, the merry nonsense challenges the offered totality, and in this sense humor is connected to the promise of happiness. To discuss the possibility of happiness, its distorted manifestations have to be analyzed, 
and to do this, Adorno offers a specific kind of non-position of criticism: ${ }^{4}$ A critic cannot put forward his or her positions as a total outsider, but he or she should not be entirely penetrated by the social ideals, either. In relation to humor, this means that it is not fundamental to offer clear guidelines for "proper" humor or how to be funny in a righteous or affirmative way. Following Fromm's philosophical position (see FROMM, 1976), humor should be considered a dynamic phenomenon, and this is the guiding premise for non-positional humor. In this respect, fixed answers to the problem of humor are not satisfying as truth - and humor in relation to it - is always historical (see FROMM, 1979). This means that concepts and their substance are always formed in the current historical situation. If humor is by its nature a dialectic concept and dynamic phenomenon, it cannot be standstill, and it should not be fetishized. Simple answers to the problem of humor (e.g. humor is conservative or humor is critical) freeze humor. Despite all the possible pitfalls, Adorno and Fromm agree that there is critical potentiality in humor and laughter. This potentiality is based on the life-affirmative humanistic attitude which can be articulated via dialectical approach.

In regard to actual comedies, both Fromm and Adorno saw the possibility of humor to express life-affirmative values. Fromm writes that Charlie Chaplin's movies express exceptional tenderness and kindness, and how The Great Dictator ends with one of the most moving speeches he had ever heard (FROMM, 1991). Adorno's relationship to Chaplin was more ambiguous. In his earlier texts, Adorno describes how Chaplin's movies represent the National Socialistic agenda, when the "swaying cornfields at the end of Chaplin's film on Hitler give the lie to the antifascist speech about freedom" (HORKHEIMER \& ADORNO, 1947, p. 119). However, after meeting Chaplin, Adorno's opinion became more affirmative. There is a revealing incident between

\footnotetext{
${ }^{4}$ Adorno discusses this approach in length in the Negative Dialectics (1966), and he argues that a negation of something does not necessarily lead to affirmation of something else.
} 
these two at a party. Adorno, in his absent-mindedness, offered to shake hands with Harold Russel, an actor who had lost his hand in the war and who wore an artificial claw instead. When they shook hands, Adorno was shocked that Russel's claw actually responded to the pressure. Of course, as Adorno did not want Russel to see his reaction, he tried to smile instead, which ended up being a disturbing grimace. Naturally, right after Russel left the party, Chaplin started to mimic the occasion. Adorno recollects: "So close to horror is the laughter that he provoked and only from close up can it acquire its legitimacy and its salutary aspect" (Adorno according to MÜLLER-DOOHM, 2005, p. 402-403).

Here Adorno expresses how the most mocking humor can be life-affirmative; and at the same moment he notes how the closeness of horror expresses the ambiguity of humor. What did Chaplin actually ridicule? Of course, it is possible that he just pinpointed the awkwardness of the situation, but following Adorno's interpretation, this hardly explains the whole incident. Instead, it appears that Chaplin noticed and ridiculed a general human tendency, general at least, for example, to those in positions of relative privilege, such as able-bodied people, to overcompensate when we encounter a human difference we did not expect, to the extent that we become ridiculous. The uneasiness of the reactions and the difficulties of formal courtesy reveal our limitedness. Our superficially polite habits hide our underlying prejudices of which we are so afraid. Thus, we fail to treat, say, people with physical differences as human beings, and instead treat them as carriers of those differences, even though we try so hard to act otherwise. This is a specific kind of reversed prejudice, which ends up being custodial instead of being respectful. In this case, Chaplin did not necessarily mock Adorno himself, but his socially adopted habits which turned against themselves. The concrete situation, in any case, is colored with uneasiness.

The uneasiness triggered by the mixture of life-affirmativeness and cruel mockery should be understood in the lines of Adorno's concept of somatic impulse (see ADORNO, 1966; HULATT, 
2014). Somatic impulse is a non-rational expression of rationality which, simply put, is a bodily expression of the wrongness of the surrounding social setting. It is the feeling that there is something wrong in the present world - without expressing how things ought to be. This impulse is not guided merely by rational thought as the rational thought can be biased. Somatic impulse is not reduced to reason, and in a sense there is non-reason present which challenges the prevailing patterns of logic. This impulse in its negativity is the expression of hope and a possibility of resistance. Adorno, of course, is not willing to offer clear positive formulations of this somatic impulse.

Criticism which does not offer fixed answers but accepts humanism can be formulated by Fromm's social psychological position on humanity. In a sense, Fromm studies the same conditions of humanity as Adorno, only in a more explicit manner. Fromm argues that it is necessary to admit that the essence of humanity is based on a paradox and on dynamic existential needs. ${ }^{5}$ In his position, one cannot claim that humanity does not ever change, but instead, it is a paradoxical problem which has to be solved in a unique historical situation (see FROMM, 1962). The central idea is that everyone shares a part of humanity, but it does not mean that there is only one way to be a true human being - we are all "One" but we are all equally unique individuals. When this uniqueness is forgotten, humanity becomes fixed and distorted. Fromm argues that if existential needs are not satisfied in a productive (that is, humane) manner, individuals will react against this, even though this reaction is not always conscious or clear. Instead, it is often manifested in the feeling of boredom or ennui (see FROMM, 1976).

\section{Socially Critical Humor}

Can humor itself be socially critical? There are plenty of comedians who appear to be critical; Jimmy Carr does not shy

\footnotetext{
${ }^{5}$ E.g. need for relatedness and frame of orientation (see FROMM, 1973).
} 
away from laughing at various cultural features, Ricky Gervais jokes all the time about the stupidity of religions, and Bill Maher questions the meaning of politics with his sarcastic style of satire, just to mention a few. The common denominator between these three (and various others) is that they all offer social criticism via ridicule. For instance, Simpson (2003) claims that political satire needs to be aggressive, and it always needs a target to attack; in this respect critical humor has an aggressive function. However, both Adorno and Fromm would point out that this kind of aggressive humor is still a part of the establishment, and their ways of performing are, despite all, guided by the laws of the culture industry. Even if comedians joke about politics or society, in the end, their humor offers relatively futile hope. Fromm and Adorno demand more from socially critical humor.

Fromm sees critical potential in jokes. For him, certain jokes ridicule the shared insanity of Western ways of living. ${ }^{6}$ In this regard, he comes close to the above humorists as they all see that with humor it is possible to reveal the silliness of our lives. For Fromm, however, laughter triggered by a joke is not a concluding remark but instead a starting point. It is essential to ponder what happens after laughter, and what the impact of the humorous occasion is. The problem with plenty of so-called critical humorists is that their influence is, eventually, impotent in regards of changing the world. To distort the Marxist maxim, a humanist humorist cannot be satisfied with laughing at our risible habits as the mission is to change the world. Often comedians offer a potentially critical moment, but the audience's laughter appears to be merely medicine for boredom; it is not a driving power to change the oppressing circumstances. If a comedian jokes about the weirdness of the

\footnotetext{
${ }^{6}$ For example, he claims that the tendency for irrational rationalization can be brought forward by the following joke: "A person who had borrowed a glass jar from a neighbor had broken it, and on being asked to return it, answered, 'In the first place, I have already returned it to you; in the second place, I never borrowed it from you; and in the third place, it was already broken when you gave it to me'"' (FROMM, 1941, p. 203).
} 
$|100|$

Socially Critical Humor: Discussing Humor...

American voting system, and people laugh, the system barely changes, and the critical power of humor falls short (see BENTON, 1988). Humor seems to be, more or less, merely a safety valve to blow off social tensions (see APTE, 1985), and at the same time a means for social control (see BILLIG, 2005). There is an ongoing discussion whether humor is by heart conservative or critical (see KUIPERS, 2008), but so far, humor researchers have most often been analyzing the contents of jokes; critical humor is considered to be something in which the pun of the joke is the one(s) in power, and via this ridiculing humor opens up a discursive space which is not possible in the sphere of normal or serious speech. However, it seems, these special speech acts most often do not further human freedom or other higher values in a productive manner. Of course, it is possible that a ridiculed politician has to stand aside if he or she cannot be taken seriously any more. However, this kind of criticism does not influence the total system of rotten politics. The wheel will keep on turning, nonetheless, as humor rarely manages to remove the wheel entirely.

If the critical potential of humor cannot be located in the content of jokes, perhaps it can be located somewhere else. Fromm and Adorno are certain that even though most of the produced humor is impotent and dull, there are genuine critical and lifeaffirmative possibilities in humor. Chaplin is one example, but there are also other insightful comedians (like the Marx Brothers) who have managed to combine their glee with the promise of happiness: for Adorno, the greatest example of a critical humorist is Samuel Beckett. In his plays, like Endgame and Waiting for Godot, Beckett illustrates how laughter has become an expression of renewed barbarism. When the protagonists of the plays, Adorno writes, decide to laugh, they offer "more the tragic presentation of comedy's fate than they are comic; in the actors' forced laughter, the spectator's mirth vanishes" (ADORNO, 1970, p. 340). Adorno does not believe that blunt joking about the horrors of the world could be emancipatory as directly facing these horrors will divert the attention from it (ADORNO, 1970, p. 234). This underlines 
the elemental problem of contemporary socially critical humor; it offers a full frontal assault against ridiculous aspects of life, but at the same time it demands insensitivity to reality. Adorno forms a critical maxim for humor: "Only when play becomes aware of its own terror, as in Beckett, does it in any way share in art's power of reconciliation" (ADORNO, 1970, p. 317).

Here the praise of humor is given in a negative sense, and this type of humor is non-positional. Humor, in Beckett's works, is not straightforward joking or vulgar slapstick, but instead a negation of fun; it is the lack of fun that makes Beckett's humor so admirable. Simon Critchley (2002) calls it a laughter that laughs at laughter. Beckett's humor is critical because it questions the whole nature of laughter. Beckett demonstrates how sick society is, and he tries to resist the shared insanity without taking clear positions or promoting easy answers to the problems of living. Beckett is absurd, but not every kind of absurdity is enough to be critical, as Adorno remarks:

\begin{abstract}
Beckett's plays are absurd not because of the absence of any meaning, for then they would be simply irrelevant, but because they put meaning on trial; they unfold its history. His work is ruled as much by an obsession with positive nothingness as by the obsession with a meaninglessness that has developed historically and is thus in a sense merited. Though this meritedness in no way allows any positive meaning to be reclaimed (ADORNO, 1970, p. 153).
\end{abstract}

Fromm's distinction between the concepts of joy and fun/ pleasure is essential to understand the negative promise of humor. He begins with the notion that we live in a world of joyless pleasures. Fromm sees how there are plenty of different kinds of pleasures - fun one of them - which are targeted at having peak experiences. Despite the intense and immediate satisfaction offered by these various pleasures, they "are nevertheless pathological, inasmuch as they do not lead to an intrinsically adequate solution of the human condition" (FROMM, 1976, p. 145). The pathology of 
| 102 |

Socially Critical Humor: Discussing Humor...

contemporary humor is that it offers merely laughter and nothing lasting. This kind of humor, following Fromm, is not conducive to joy. This joylessness of fun is what Beckett underlines in his plays and books.

In opposition to fun, joy is not a sudden peak experience but "a plateau, a feeling state that accompanies the productive expression of one's essential human faculties. Joy is not the ecstatic fire of the moment. Joy is the glow that accompanies being" (FROMM, 1976, p. 146). Following Fromm, the demand for humor is that it should be related to this glow and creative power. As a critical theorist, Fromm does not give fixed guidelines for proper ways of amusement but bases his insights on the paradoxical core of humanity; his thinking about humor and laughter has to be evaluated in relation to this background. In this light, it becomes clear that humor cannot be considered as a means to or tool for anything, because an instrumental approach to humor fetishizes it. Instead, the question becomes: how does humor reflect humanity?

The conclusion is that the promise of happiness cannot be found within humor itself, but only when humor is transformed into something else, when it plays with cracks in society. Lydia Goehr notes how laughter can be transformed into, "or displaced by, cruelty, aggression, or malice, but embarrassment [can be] displaced by relief and ease" (GOEHR, 2005, p. 328). However, even this idea should not be taken as a fixed answer to the problem of humor, as it easily distorts the dynamic core of humor.

As it happens, modern humor catalogues appear to be full of examples of the above kind of humor. There is plenty of cruel mockery which is met by relieving laughter. It is often claimed that humor has to shock and disturb; and that we have to be able to laugh at everything, even the most horrible occasions of human life. Generally, there is a wide belief that laughter gives us distance and in this way allows us to grasp the most horrendous aspects of humanity. Martin Shuster (2013) has argued that humor becomes funnier when it is offensive, and how sexist jokes are funnier because of their sexism. 
Both Adorno and Fromm would reject this kind of appraisal. Instead, they would put the meaning of humor under scrutiny. Simple answers claim that humor should trigger laughter, evoke mirth, and so forth. For instance, Shuster - who focuses on contents of jokes and their relation to funniness - states that "humor helps initiate us into and maintain us within a form of life" (SHUSTER, 2013, p. 627). Socially critical humor refutes this idea, as it does not aim to maintain the prevailing form of life. Socially critical humor challenges the idea that humor's goal is to trigger laughter or to be amusing. In a negative framework, humor actually does not have a goal, but it should be understood as a reflection of the way of being; even if the life around us is overwhelmingly negative and most of the produced humor dulling, humor has the potential to cause uneasiness as it leaves room for an individual to realize the falsity of the current societal setting. It is possible for humor to be in line with somatic impulses and existential needs; it may trigger laughter and anxiety at the same time.

\section{Concluding remarks}

Even though neither Fromm nor Adorno did explicit research on the philosophy of humor, they share inspirational ideas about the nature of humor. Their most important insights are not about what humor is but instead come when they analyze humor as a cultural phenomenon. This position opens up possibilities for future critical humor research which is aware of the influences of social surroundings on humor and laughter. Following Fromm and Adorno it is possible to draw critical premises about humor and culture, and to question unfounded beliefs concerning humor. What is often called critical humor, like political satire and irony, may actually be impotent. For humor to be profoundly critical, it is not enough to joke about politics or racism or sexism, as humor has to challenge its own current forms. Humor, to be socially critical in the sense meant by Adorno and Fromm, has to meet (at least) four preconditions: First, humor has to be based on a life-affirmative frame of reference in a dialectic sense; and second, it has to be 
non-positional, as discussed above. Third, humor cannot be instrumental. Fourth, humor has to challenge the limits of humor (but not necessarily, say, the limits of morality). With this in mind, Adorno and Fromm remind how there is displeasure in pleasure, how unfunniness can be most amusing, and how laughter is often non-laughter.

The dialectical thinking emphasized by both Fromm and Adorno includes exaggeration, but this involves a methodological aspect: it challenges thoughts to the extreme, even to the point where thoughts turn their backs on themselves. This may sound rather humorous, but it is the central point of a critical theory of humor. It drives towards absurdity in order not to be captivated by the objective madness. Their criticism does not only touch on certain beliefs about humor but it is intertwined with the question of what it means to be a human being. Critical humor research, in this aspect, is always research about humanity, too. Both Adorno and Fromm highlight the importance of questioning the presupposed validity of our everyday assumptions of, say, reason, morality, and cultural excellence. To found this criticism, it is necessary to bring Adorno and Fromm back to a reciprocal dialogue; this combination offers fruitful possibilities for further humor research. In later research, it is important to develop and operationalize the central concepts to be empirically tested.

It is pivotal to understand that a critical theory of humor does not settle for a close analysis of particular examples of humor. As such it bears repeating that a critical theory of humor questions the prevailing illusions about humor and laughter in relation to human freedom and to the possibility of social change. These are the aspects from which humor and laughter have to be evaluated as human attributes. Critical theory of humor stands in opposition to the conventional assumptions about humor. It challenges clinical studies about humor and their data; it offers new kinds of interpretations about humor and laughter - and about humanity itself. It is not satisfied with the manifest dimensions of personality but strives to understand the latent aspects of personality. It tries to reach beyond the simple answers to the problem of humor. The 
task is to criticize inhumane practices and tendencies - even when they are in the form of innocent humor. It all comes down to the question of whether a good life can be lived within a sick society; what the basic premises are on which a society is built; and how one can live a responsible life in this setting. The central question is how humor progresses or regresses these possibilities. ${ }^{7}$

Based on the combination of the social criticism by Fromm and Adorno, a critical theory of humor does not offer clear fixed answers about humor, as humor is considered as a dynamic phenomenon. However, it does not shy away from criticism or suggestions. Ultimately, even humor is based on ideals, and the decisive question is to which ideals humor is attached. A few preliminary ideals can be listed: human individuation, a possibility to be different and to understand the simultaneous difference and sameness between human beings. Humanity itself is ever-changing and existential questions have to be considered in a certain historical period and cultural setting. Therefore, one cannot offer universal explanations of humanity - or humor. If humor is based on the idea of being a part of the universal and still assuring individuality, it can be considered positive. Also, it is still possible to criticize humor when it turns its back against universal individuality, and offers nothing but the sameness of it all.

\section{References}

ADORNO, T. Minima Moralia. Trans. D. Redmond. 1951. Retrieved from: <https://www.marxists.org/reference/archive/ adorno/1951/mm/index.htm>. Date of access: 11/08/2016.

Negative Dialectics. Trans. E. Ashton. London: Routledge \& Kegan Paul, 1966/1973.

\footnotetext{
${ }^{7}$ In future research, it will be essential to compare these ideas to Sigmund Freud's theory about jokes and humor, as both Fromm and Adorno work with psychoanalysis, too.
} 
Aesthetic Theory. Trans. R. Hullot-Kentor. London: Continuum, 1970/2002.

The Culture Industry: Selected Essays on Mass Culture. Edited by J. M. Bernstein. London/New York: Routledge Classics, 1991/2002.

APTE, M. Humor and Laughter: An Anthropological Approach. Ithaca: Cornell University Press, 1985.

BAKER, B. The Power of a Smile - How Smiling Can Change Your Life and Change the World. 2012. Retrieved from: $<$ http://www.startofhappiness.com/the-power-of-a-smile/>. Date of access: 14/08/2016.

BENTON, G. The Origins of the Political Joke. In: POWELL, C.; PATON, G. (eds.). Humour in Society: Resistance and Control. Basingstoke: MacMillan, 1988, p. 33-55.

BERGSON, H. Laughter. An essay on the Meaning of the Comic. Trans. C. Brereton and F. Rothwell. New York: The Macmillan Company, 1913/1899.

BILLIG, M. Laughter and Ridicule: Towards a Social Critique of Humor. London: SAGE Publications, 2005.

CRITCHLEY, S. On Humour. London: Routledge, 2002.

DAVIES, C. Jokes and Targets. Bloomington \& Indianapolis: Indiana University Press, 2011.

FERGUSON, M.; FORD, T. Disparagement Humor: A Theoretical and Empirical Review of Psychoanalytic, Superiority, and Social Identity Theories. HUMOR, v. 21, n. 3, p. 283-312, 2008.

FEUER, M. Stop Laughing: Max Horkheimer and Theodor Adorno on Laughter, False Happiness, and the Culture Industry. 2015. Retrieved from: <https://schlemielintheory.com /2015/01/18/stop-laughing-max-horkheimer-and-theodor-adornoon-laughter-false-happiness-and-the-culture-industry/>. Date of access: 19/07/2016. 
FRIEDMAN, L. The Lives of Erich Fromm: Love's Prophet. New York: Columbia University Press, 2013.

FROMM, E. Escape from Freedom. New York: Open Road/ Integrated Media, 1941/2013.

Man for Himself: An inquiry into the Psychology of Ethics. London/New York: Routledge Classics, 1947/2003. 1955/1990

The Sane Society. New York: Henry Holt and Company,

Beyond the Chains of Illusion: My Encounter with Marx and Freud. New York: Continuum, 1962/2006.

To Have or To Be? New York: Open Road/Integrated Media, 1976/2013.

Greatness and Limitations of Freud's Thought. New York: Open Road/Integrated Media, 1979/2013.

For the Love of Life. Trans. R. and R. KIMBER. New York: The Free Press, 1983/1986.

The Pathology of Normalcy. New York: AMHF, 1991/2010.

GOEHR, L. Philosophical Exercises in Repetition: On Music, Humor, and Exile in Wittgenstein and Adorno. In: BERGER, K., NEWCOMB, A. (eds.). Music and Aesthetics of Modernity: Essays. Cambridge/London: Harvard University Press, 2005, p. 311-340.

GRAY, A., PARKINSON, B.; DUNBAR, R. Laughter's Influence on the Intimacy of Self-Disclosure. Human Nature, v. 26, n. 1, p. 2843, 2015.

HORKHEIMER, M.; ADORNO, T. Dialectic of Enlightenment: Philosophical Fragments. Trans. E. Jephcott. Stanford: Stanford University Press, 1947/2002.

HULATT, O. Normative Impulsivity: Adorno on Ethics and the Body. International Journal of Philosophical Studies, v. 22, n. 5, p. 676-695, 2014. 
KUIPERS, G. The sociology of humor. In RASKIN, V. (ed.). The Primer of Humor Research. Berlin/New York: Mouton de Gruyter, 2008, p. 361-398.

LEWIS, P. Cracking Up: American Humor in a Time of Conflict. Chicago: University of Chicago Press, 2006.

MCLAUGHLIN, N. Origin Myths in the Social Sciences: Fromm, The Frankfurt School and the Emergence of Critical Theory. Canadian Journal of Sociology, v. 24, n. 1, p. 109-139, 1999.

MÜLLER-DOOHM, S. Adorno: A Biography. Trans. R. Livingstone. Cambridge: Polity Press, 2005.

ORING, E. Engaging Humor. Urbana and Chicago: University of Illinois Press, 2003.

PROVINE, R. Laughter: A Scientific Investigation. New York: Viking, 2000.

RUCH, W. Foreword and Overview. Sense of humor: A new look at an old concept. In: RUCH, W. (ed.). The Sense of Humor: Explorations of a Personality Characteristic. Berlin/New York, Mouton de Gruyter, 1998.

SEPP ÄLÄ, E. 7 Research-Based Reasons to Laugh Every Chance You Get. 2015. Retrieved from: <https://www.psychologytoday. com/blog/feeling-it/201503/7-research-based-reasons-laugh-everychance-you-get $>$. Date of access: 27/07/2016.

SHUSTER, M. Humor as an Optics: Bergson and the Ethics of Humor. Hypatia, v. 28, n. 3, p. 618-632, 2013.

SIMPSON, P. On the Discourse of Satire: Towards a Stylistic Model of Satirical Humour. Amsterdam: John Benjamins Publishing Company, 2003.

SMUTS, A. The Ethics of Humor: Can Your Sense of Humor Be Wrong? Ethical Theory and Moral Practice, v. 13, n. 3, p. 333-347, 2010. 